\title{
An Analysis of Imperative Sentences of the Martian Movie and Their Subtitling
}

\author{
Muhammad Mahfudz Asrori ${ }^{1}$, Hastuti Retno Kuspiyah², and Ainur Rohmah ${ }^{3}$ \\ Pendidikan Bahasa Inggris STKIP Nurul Huda Sukaraja \\ 1Mahfudzas28@gmail.com \\ 2retno@stkipnurulhuda.ac.id
}

Abstract

This study concerns with the "An Analysis of Imperative Sentences of The Martian Movie And Their Subtitling". This study purposes problems are What the types of Imperative Sentence on the Martian Movie and their subtitling?. The main objective of this study is to know the imperative sentence of the martian movie and its subtitling. Therefore, this analysis used a descriptive qualitative method, documentation technique is used in collecting the data. By this method, the writer uses the subtitling of The Martian movie as the source of data. Based on the findings, the writer found that there are 2 types of imperative sentences, namely; (1) positive imperative sentence consisting of 70 data or $84.33 \%$, and (2) negative imperative sentence consisting of 13 data or $15.67 \%$. The most occurred was a positive imperative sentence consisting of 70 data or $84.33 \%$.

Keywords: Analysis, Imperative Sentence, The Martian Movie.

\section{INTRODUCTION}

Language played an important role in our daily communication. People use it to communicate with each other to express their ideas, thought, and feeling. The language was also used to establish the relationship among people. According to Croft (2000:87) language is a fundamentally social interactional phenomenon. It means that people need language to share their thought with others to have a good relationship with them. As a social interactional phenomenon, it is always developed along with people's minds. Language changes and develops day by day based on the people who use it. One of the language development is created new words by using existed words.

A sentence was a group of words at least consists of subject and predicate and has an idea. According to Frank (1972: 220) "sentence is full of predication containing a subject plus a predicate with a finite verb. Then, he added the types of sentences used in subtitling are declarative sentences, interrogative sentences, imperative sentences, and exclamatory sentences. In this study, the writer discussed the imperative sentence. The imperative sentence was a sentence that was used was suing orders or directives. Sometimes, the imperative sentence ends with an exclamation mark. Aarts and Aarts (1982: 96), mention that there were four functions in the imperative sentence: Command, Desire, Invitation, and Warning.

Based on the above statement, the writers choose the film as a source of data. Therefore, the movie titled "The Martian" by Ridley Scott became the object of study. The reason why the writer chose the imperative sentence as the title of studied because when the writers follow the grammar lectures and syntax the writers learn about imperative sentences and writers were interested to find the form of imperative sentences in everyday activities and the main basis using imperative sentence is to have someone to do something because the writer wants to know about the form and function in the communicated of the imperative sentence.

In this study, the writer intended to focus on the problem as follows: What are the types of Imperative Sentence on the Martian Movie and their subtitling?

\section{Sociolinguistics}

sociolinguistics is a part of sociolinguistics study which focuses on language which is dealing 
with the social and cultural phenomenon in one society (Yule, 2010:254). It usually explores the field of language, society, and things that are related to social sciences, especially psychology, anthropology, and sociology. The idea proposed by Yule is also in line with Trudgill. Trudgill (2000: 32) study of sociolinguistics is related to a cultural phenomenon so that it can affect the way people speak or talk since it is determined by the social context.

By those two linguists, Holmes (2013: 01) also says that people who study linguistics will probably concern with describing people's different ways of speaking in different social contexts. Moreover, Holmes argues that sociolinguists also try to investigate the use of language to convey messages. As language functions to convey messages, there must be social interactions between the members of the community.

\section{Concept of movie}

A movie becomes important in our life. Vassiliou (2006:2) A film or movie provides us with the illusion of movement and sound and suspends our disbelief to provide an entertaining, immersive experience for the viewer. Film or movie events describe events common to most films, e.g. action, dialogue, suspense, and emotional events(Vassiliow, 2006:2).

The movie as a medium of mass communicated is a means of the nation's intellectual life, the development of self-potential, noble character building, the promotion of community welfare, and the vehicle promotion of Indonesia in the international world, so film and film Indonesia needs to be developed and protected (UUD, 2009:33).

\section{Concept of Subtitling}

Subtitled videos representing words and pictures in oral and visual form are more probable to activate both coding systems in the processing than words or pictures alone. According to the dualcoding theory proposed by Paivio (1971:1), when pictures are associated with the meaning, the number of signals connected to the message increases.

According to Reich in Gorjian (2014:1015), subtitling is a branch of translation called audiovisual translation in which viewers can read statements of dialogues on the screen as well as watch the images and listen to the dialogues. Gorjian (2014:1015), believes that captioning and subtitling have the same definitions although some make a distinction and believe that captioning is considered to be for both deaf and hearing-impaired viewers while subtitling is special to hearers.

\section{Concept of Imperative Sentence}

According to Frank (1972: 220) "sentence is full of predication containing a subject plus a predicate with a finite verb". The kinds were declarative sentences, interrogative sentences, imperative sentence, and exclamatory sentences. From the four kinds of the sentence above, in this studied the writer will analyze the imperative sentence.

Imperative sentences were sentences that request the person we are speaking to do or not to do something. Based on the intonation used, imperative sentences can be divided into commands, requests, invitations, and warnings. An imperative sentence was one that gives a command, direction, or request. By Swan (1982:77), the imperative is the base form of a verb used to give orders, to give prohibition, make a suggestion, etc. it means that imperative sentence uses the basic verb or verb one to give an order or to make a suggestion. Another assumption about the imperative sentence comes from Hall (1993:224) who said that imperative sentences are used to express a command or request.

According to Hall (1992: 224), there are two types of imperative sentences they are :

a. Positive imperative sentence

A positive imperative sentence gets the hearer to do something. According to Hornby(1976:193) positive imperative sentence can be conveyed in various ways; command, prohibition, request, suggestion, invitation, and giving advice. The subject of an imperative 
sentence can be understood although the speaker does not mention it. For examples:
a) Keep silent!
b) Sit down, please!
c) Be positive!

b. Negative imperative sentence

A negative imperative sentence provides a request or suggestion to the addressee no to do something. It can be a prohibition or warning. It is always signaled by the markers that don't or don't be before an imperative sentence (Drummand, 1972:23). For examples:

a) Don"t throw the ball!

b) Don"t be a lazy boy!

Frank(1972:57) writes a negative imperative sentence can be indicated by let's not for the plural person. For examples:

a) Let"s not open the door.

b) Let"s not blame each other!

\section{METHODOLOGY}

The method that the writer used was descriptively studied. According to Noor (2013:34), a Descriptive study has studied that attempts to describe a phenomenon, events, events that occur in the present moment. A descriptive study determines and reports the thing. it means that descriptive studied, the studied happen naturally, and the studied has no control over the condition and the situation, and can only measure what already exist Descriptive studied focuses on actual issues as they are at the time of the studied. "Descriptive is the data collected in the form of words, images, and not the numbers" (Moleong, 2014:11).

The object of the studied is all aspect that becomes a target in the studied. The object of this studied was to explain the types of the imperative sentence of the Martian movie and their subtitling.

\section{The technique for Collecting Data}

Data collection is important to determine the result of the study. In this study, the procedure used in the data collection is: (1) watching the movie and read the script; (2) identifying the imperative sentence used in the script and the Martian subtitling; (3) making conclusions based on the data analysis.

\section{The technique for Analyzing the Data}

After collection, the data, The writer analyzed them the step of processing the data are as follow: 1 . Collecting references relevant to the analysis of the movie; 2 . Watching and reading the script of the Martian movie; 3. Identifying the imperative sentence in the movie; 4. Codifying the Positive and Negative Imperative Sentence; 5 . Making conclusions based on data analysis

\section{RESULT AND DISCUSSION}

It was found that the transcripts of the film "The Martian" movie used all of the types of imperative sentences. Then, it means in the movie there was an imperative sentence. The total utterance containing the imperative sentence in the "The Martian" movie is 83 data.

The most dominant use of imperative sentences in the movie was a positive imperative sentence that occurred by 70 data $(84.33 \%)$. It shows that most of the data are contained the positive imperative sentences. From the data above, the writer found some positive imperative sentences from the movie as presented in Table 1. 
Table 1

The Result of Positive Imperative Sentences

\begin{tabular}{|c|c|c|}
\hline No & Positive Imperative Sentences & Time \\
\hline 1 & Let's make NASA proud & 00:02:09 \\
\hline 2 & Shut'em off. & 00:03:08 \\
\hline 3 & You should come inside... & $00: 03: 30$ \\
\hline 4 & Let's wait it out. & $00: 04: 25$ \\
\hline 5 & WATNEY, REPORT! & $00: 05: 50$ \\
\hline 6 & Get to the MAV and prep for launch. & $00: 06: 24$ \\
\hline 7 & Get moving & $00: 06: 30$ \\
\hline 8 & Get to the ship. & $00: 06: 32$ \\
\hline 9 & Go! & $00: 06: 32$ \\
\hline 10 & Give it a try & $00: 07: 18$ \\
\hline 11 & Try the radar. & 00:07:20 \\
\hline 12 & You need to get back to the ship. Now & $00: 08: 10$ \\
\hline 13 & Ready for launch. & $00: 08: 29$ \\
\hline 14 & Launch. & $00: 08: 34$ \\
\hline 15 & Let's do the math... & $00: 20: 58$ \\
\hline 16 & I need you to authorize my satellite time. & $00: 29: 42$ \\
\hline 17 & I need the emergency contact number for Dr. Kapoor. & $00: 32: 36$ \\
\hline 18 & Prove it to me. & $00: 32: 52$ \\
\hline 19 & They already think he's dead. & $00: 33: 29$ \\
\hline 20 & I'm gonna die up here... & $00: 34: 26$ \\
\hline 21 & "Everything will be fine" & $00: 38: 02$ \\
\hline 22 & Make it happen. & $00: 40: 15$ \\
\hline 23 & Tell him... & $00: 54: 58$ \\
\hline 24 & It's time, & $00: 56: 46$ \\
\hline 25 & Go ahead. & $00: 57: 13$ \\
\hline 26 & The data dump is almost complete. & $00: 57: 15$ \\
\hline 27 & You were following orders. & $00: 59: 27$ \\
\hline 28 & I ask for a picture & 01:01:27 \\
\hline
\end{tabular}


30 | Channing: English Language Education and Literature Vol. 4 No. 1 April 2019 Halaman: 26-32

\begin{tabular}{|c|c|c|}
\hline 29 & Just be grateful you got something, & $01: 01: 30$ \\
\hline No & Positive Imperative Sentences & Time \\
\hline 30 & Ineed something & $01: 01: 33$ \\
\hline 31 & Is your team still on schedule? & 01:01:48 \\
\hline 32 & Get him inline & $01: 02: 10$ \\
\hline 33 & I hate this margin & $01: 02: 13$ \\
\hline 34 & Custom leak detected & 01:03:07 \\
\hline 35 & The airlock is leaking. & 01:03:18 \\
\hline 36 & The crops are dead.. & $01: 06: 59$ \\
\hline 37 & Wake up. & $01: 12: 37$ \\
\hline 38 & I need more coffee... & $01: 13: 21$ \\
\hline 39 & Give me a number. & $01: 13: 58$ \\
\hline 40 & To stretch Watney's rations four more days. & $01: 14: 34$ \\
\hline 41 & It's on me, & $01: 14: 42$ \\
\hline 42 & You've got your two weeks. & $01: 14: 43$ \\
\hline 43 & Get it done. & $01: 14: 44$ \\
\hline 44 & Begin Launch Status Check. & $01: 16: 14$ \\
\hline 45 & Lock the doors & $01: 18: 22$ \\
\hline 46 & Flight, we're getting a large precession! & $01: 13: 37$ \\
\hline 47 & I need you to do something for me. & $01: 18: 54$ \\
\hline 48 & I need you to check on my parents. & 01:19:02 \\
\hline 49 & Please tell them & $01: 19: 36$ \\
\hline 50 & You should hang up the phone. & $01: 22: 31$ \\
\hline 51 & Get out. & 01:25:07 \\
\hline 52 & Can you report? & $01: 57: 18$ \\
\hline 53 & Do it. & $01: 58: 41$ \\
\hline 54 & Hang on. & $01: 58: 43$ \\
\hline 55 & Are you hearing this? & 02:01:52 \\
\hline 56 & Open Airlock 1 & 02:03:26 \\
\hline 57 & Open A1 & $02: 03: 41$ \\
\hline 58 & Hold this & 02: 03:54 \\
\hline
\end{tabular}


An Analysis of Imperative Sentences of the Martian Movie and Their Subtitling 31 Muhammad Mahfudz Asrori', Hastuti Retno Kuspiyah², dan Ainur Rohmah ${ }^{3}$

\begin{tabular}{|l|l|c|}
\hline 59 & Bomb is set. & Positive Imperative Sentences \\
\hline No & \multicolumn{1}{|c|}{ Time } \\
\hline 60 & Close the door! & $02: 05: 05$ \\
\hline 61 & Open d3! & $02: 05: 09$ \\
\hline 62 & Leave it open! & $02: 05: 12$ \\
\hline 63 & Open B2! & $02: 05: 42$ \\
\hline 64 & Blast the bomb & $02: 06: 06$ \\
\hline 65 & Hook me up & $02: 06: 53$ \\
\hline 66 & Adjusting course. & $02: 08: 11$ \\
\hline 67 & Prep the sickbay. & $02: 09: 27$ \\
\hline 68 & Meet me in Airlock Two. & $02: 09: 30$ \\
\hline 69 & Hold him & $02: 10: 15$ \\
\hline 70 & Close the pairs & $02: 10: 21$ \\
\hline
\end{tabular}

The second stage was the negative imperative sentence which contains 13 data (15.67\%). Details of negative imperative sentences are presented in Table 3.

Table 2

The Result of Negative Imperative Sentences

\begin{tabular}{|l|l|c|}
\hline No & \multicolumn{1}{|c|}{ Negative Imperative Sentences } & Time \\
\hline 1 & Do not open until thanksgiving & $00: 20: 42$ \\
\hline 2 & It's not gonna happen. & $00: 29: 44$ \\
\hline 3 & In a year, people won't care anymore. & $00: 31: 20$ \\
\hline 4 & I'm not turning the beat around. I refuse to. & $00: 34: 39$ \\
\hline 5 & "Don't Dig Up The Big Box of Plutonium, Mark..." & $00: 37: 41$ \\
\hline 6 & No more humans. & $00: 37: 49$ \\
\hline 7 & Don't say & $00: 39: 33$ \\
\hline 8 & Looking forward to not dying & $00: 54: 07$ \\
\hline 9 & It wasn't... & $00: 59: 22$ \\
\hline 10 & It's not gonna work & $01: 01: 31$ \\
\hline 11 & We can't afford any miscommunicated & $01: 02: 11$ \\
\hline 12 & It's not a debate & $02: 06: 00$ \\
\hline 13 & Don't make me laugh & $02: 11: 01$ \\
\hline
\end{tabular}


The last finding was that the writer proved several theories, the findings show that there are two types of imperative sentences, namely; positive imperative sentences and negative imperative sentences. From the above findings, the writer found that from all 83 data in the Imperative sentence, the writer state that the positive imperative sentence is 70 data or $84.33 \%$ and the negative imperative sentence is 13 data or $15.67 \%$.

\section{CONCLUSION}

Based on the results and discussion of the research that has discussed the An Analysis Of Imperative Sentences Of The Martian Movie And Their Subtitling, the writer writes the following conclusions:

There are two types of imperative sentences found in the subtitling of The Martian movie. They are positive imperative sentences and negative imperative sentences. From 83 data, there are 70 data or $84.33 \%$ belong to positive imperative sentence, 13 data, or $15.67 \%$ belong to a negative imperative sentence. From the data and the analysis found by the Writer about an imperative sentence on The Martian movie, the positive imperative sentence is a common imperative sentence that occurs in the subtitling. It can be seen from 83 data, there are 70 data or $84.33 \%$ belong to positive imperative sentences. The most dominant use of the imperative sentence in the movie was a positive imperative sentence that occurred by 70 data $(84.33 \%)$.

\section{REFERENCIES}

Aarts, F, and Aarts. (1982). English Syntactic Structure: Function and Categories in Sentences Analysis. Oxford: Pergamon Press.

Croft, W. (2000). Explaining Language Change: An Evolutionary Approach. London: Longman.

Drummond, G. (1972). English Sentences Practice, Logman.

Fandango, The Martian (Synopsis. Access at 20:00, Mei 2th, 2017, from https://www.fandango.com/the-martian-183474/plot-summary).

Frank, M. (1972). Modern English: A Practical Reference Guide. New Jersey: Prentice Hall, Inc.

Gorjian, B. (2014). the effect of movie subtitling on incidental vocabulary learning among EFL learners. Iran: Department of TEFL, Abadan Branch, Islamic Azad University, Abadan.

Hall, E. J. (1992). Grammar for use: a realistic approach to grammar study for immediate and practical application. USA: Voluntad Publisher, Inc.

Holmes, J. (2013). an Introduction to Sociolinguistics (Fourth Edition). New York: Routledge.

Moong, L. J. (2014). Metodologi penelitian kualitatif. Bandung: PT. RemajaRosdakarya.

Noor, J.( 2013). Metodologi penelitian, Jakarta: KencanaPrenada Media Group.

Paivio, A. (1971). Imagery and verbal processes. New York: Holt, Rinehart, and Winston.

Swan, Micahel. (1982). Practical English language, Oxford: Oxford University Press.

Trudgill, P. (2000). Sociolinguistics: An Introduction to Language and Society (Fourth Edition). London: Penguin Group.

Venuti, L. (2000). "language, community, utopia". The translation studies reader. Ed. Lawrence Venuti. London: Routledge.

Yule, G. (2010). the Study of Language (Fourth Edition). Cambridge: Cambridge University 